\title{
Badania nad kuratelą sądową w Polsce po wprowadzeniu ustawy o kuratorach sądowych
}

\begin{abstract}
Abstrakt
Celem tego artykułu jest próba ukazania dominujących tendencji w problematyce, metodach oraz organizacji badań naukowych nad kuratelą sądową w Polsce po wejściu w życie ustawy z dnia 27 lipca 2001 o kuratorach sądowych. Analizie została poddana zawartość rodzimych opracowań naukowych o charakterze empirycznym z udziałem kuratorów sądowych oraz ich podopiecznych. Pozwoliła ona ustalić, że problematyka omawianych badań empirycznych dotyczy głównie trudności i ograniczeń w pracy kuratora sądowego, a także efektywności jego oddziaływań resocjalizacyjnych. Natomiast dominującymi metodami w badaniach nad kuratelą sądową w Polsce są metody zorientowane ilościowo.
\end{abstract}

Słowa kluczowe: kurator sądowy, system kurateli sądowej w Polsce, badania empiryczne.

\section{Research on the Polish Probation System after the Adoption of the Act on Probation Officers}

\begin{abstract}
The purpose of this work is to show the dominant tendencies in the issues, methods, and organization of scientific research on the probation system in Poland after the Act of 27 July 2001 on probation officers entered into force. The analysis includes domestic empirical research works with the participation of probation officers and their charges. It shows that the issue of the discussed empirical research concerns mainly difficulties and limitations in the work of probation officers and the effectiveness of their work for resocialization. Quantitative methods dominate in research on the probation system in Poland.
\end{abstract}

Keywords: probation officer, probation system in Poland, empirical research.

* Uniwersytet Łódzki, Wydział Nauk o Wychowaniu. 


\section{Wprowadzenie}

We współczesnej pedagogice resocjalizacyjnej szczególny akcent kładzie się na rolę oddziaływań w środowisku otwartym (Pospiszyl, Konopczyński 2007; Bałandynowicz 2011; Michel 2011; Sawicki, Konarzewski 2014). W Polsce mimo dominujących, instytucjonalnych form resocjalizacji (por. Konopczyński 2015) zagadnienie to stanowi ważny fragment analiz i dociekań naukowo-badawczych. Sytuacja dotyczy zwłaszcza możliwości pracy wychowawczej i socjalnej z osobami, które $\mathrm{z}$ różnych powodów znajdują się $\mathrm{w}$ centrum uwagi formalnej reakcji kontroli społecznej lub są skazane. Zagadnienia te analizowane są przez pryzmat niewydolności systemu oraz niewykorzystanych szans, jakie dają istniejące instrumenty prawne i pozainstytucjonalne formy pracy z nieletnimi, takie jak: mediacje czy nadzór kuratora (Szczepanik, Staniaszek, Jaros 2018) oraz problemów osób, które opuszczają mury placówki wychowawczej (Sikora 2015, 2017) czy penitencjarnej, szczególnie w ramach tzw. przedterminowego warunkowego zwolnienia (Gogacz 2015). Szczególnie w ostatnim przypadku niezbędnym elementem i narzędziem „kontynuacji” resocjalizacji instytucjonalnej w warunkach środowiska otwartego jest kurator sądowy (zawodowy lub społeczny).

Kurator to zawód silnie wpisany w sądownictwo i prawo, dlatego też często opisywany jest przez pryzmat ustawodawstwa i w kontekście obowiązujących przepisów prawa. Istnieje wiele publikacji poświęconych kuratorowi sądowemu, w których znaleźć można jedynie charakterystykę jego pracy w odniesieniu do obowiązujących aktów prawnych. Praca kuratora analizowana jest w silnym związku z aktami normatywnymi, a ramy definiowania poszczególnych właściwości i kompetencji narzucają konkretne przepisy prawne (por. Gromek 2001; Szymanowski 2003; Kępka 2007; Jedynak, Stasiak 2008; Liszke 2009; Lewicka-Zelent, Lasota 2018; Stępniak 2014; Jurczyk, Staniucha 2015; Nanowska 2016; Kusztal, Muskała 2018). Tego rodzaju analizy przeważnie pojawiają się przy okazji zmian w ustawodawstwie dotyczących kurateli sądowej, przed ich wprowadzeniem lub po ich wejściu w życie. W takich pracach można znaleźć analizę, interpretację lub wyjaśnianie poszczególnych aktów normatywnych, a szczególnie zalecenia sposobów ich wdrażania w praktyce. Analizy te przeważnie mają charakter normatywny i opisowy. „Mówią” wiele o zawodzie kuratora, ponieważ dowodzą, że porusza się on przede wszystkim w ramach prawnych i za pomocą instytucji prawnych. Bywa więc, że autorzy tych publikacji drobiazgowo opisują prace kuratorów przez pryzmat jego obowiązków (Jurczyk, Staniucha 2015) oraz uprawnień, które często przywodzą na myśl procedury charakterystyczne dla organów ścigania. Najlepszą ilustracją jest przesunięcie zadań z obowiązków, które przypadały wcześniej funkcjonariuszom policji na kuratorów (np. badanie stanu trzeźwości podopiecznych za pomocą zastawów umożliwiających wykrycie zażywanych środków psychoaktywnych). Nic więc dziwnego, że mimo wpisywania w rolę społeczną kuratora tzw. resocjalizacji w środowisku otwartym to $\mathrm{w}$ istocie jest to 
zawód bliższy profesjom prawno-dyscyplinującym i kontrolującym niż pracy prawno-socjalnej czy pedagogice (por. Stępniak 2010).

W artykule dokonam przeglądu badań poświęconych kurateli sądowej w Polsce. Moim celem jest ukazanie dominujących tendencji w podejmowanej przez badaczy problematyce, metodach oraz organizacji badań naukowych prowadzonych wśród kuratorów sądowych i z ich udziałem. Zamierzam przeanalizować prace empiryczne pod kątem: dominujących strategii badawczych (metod i organizacji badań) oraz problematyki badawczej. Innymi słowy, będę poszukiwać odpowiedzi na następujące pytania: jaka problematyka jest dominująca w badaniach na temat kurateli sądowej w Polsce? Jaki rodzaj badań (jakościowe czy ilościowe) jest najczęściej wykorzystywany w badaniach pracy kuratorów sądowych? W końcu, co się wiąże z ostatnim pytaniem: po jakie metody doboru próby badawczej sięgają badacze?

Analizie poddałam zawartość rodzimych opracowań naukowych poświęconych pracy kuratorów sądowych. Posługiwałam się dwoma kryteriami doboru prac: czas wydania (publikacje po 2001 r.) oraz ich charakter (prace empiryczne). Wskazana cezura czasowa nie jest przypadkowa. W 2001 r. weszła w życie ustawa o kuratorach sądowych określająca status prawny kuratorów sądowych oraz ogólny zakres ich zadań (Dz.U. z 2001 r., Nr 98, poz. 1071). Objęłam analizą publikacje, które zostały wydane po 2001 r., ponieważ chciałam, by ukazywały obraz kurateli sądowej po wprowadzeniu dokumentu, który w całości reguluje jej struktury działania. Aby osiągnąć założony cel, niezbędny był przegląd badań, a nie analiz czy interpretacji istniejących przepisów prawa. Ponadto zaznaczę, że prace, jakie analizowałam, stanowiły monografie naukowe, prace pod redakcją, artykuły w czasopismach naukowych, a także raporty (pod warunkiem, że „posiadały” odpowiednio rozbudowane informacje o metodologii badań).

Poszukiwania rozpoczęłam od wyboru opracowań, które w swoim opisie zawierały podstawowe kategorie pracy kuratora sądowego. Słowami kluczowymi, jakich szukałam, były więc obok „kurateli sądowej”/„kuratora sądowego”: kuratorska służba sądowa, probacja, dozór oraz nadzór.

Ostatecznie wybrałam do analizy 44 opracowania, które spełniały założone przeze mnie kryteria czasu i rodzaju (charakter empiryczny). Zdaję sobie sprawę, że nie dotarłam do wszystkich wydanych po 2001 r. opracowań naukowych. Przeanalizowałam tylko te prace, które znajdują się w zasobach internetowych (repozytoriach, na stronach pism naukowych i serwisach społecznościowych dla naukowców). Zdecydowałam się na analizę wyłącznie publikacji w otwartym lub wolnym dostępie. Było to podyktowane nie tylko nieskrępowanym niczym zasięgiem, ale także przekonaniem, że takie publikacje cieszą się największą popularnością, a tym samym „uczestniczą” w wytwarzaniu specyficznej wiedzy, która jest przedmiotem mojego przeglądu badań. Wyjątek stanowiły monografie. Zwykle nie są one dostępne w całości w zasobach internetowych, a tylko we fragmentach. Po zapoznaniu się z dostępnymi częściami książek mogłam podjąć decyzję o zakwalifi- 
kowaniu materiału (lub nie) do moich analiz, biorąc pod uwagę przyjęte kryteria doboru. Dokonałam pogłębionej analizy ich zawartości pod kątem następujących zagadnień: dominująca problematyka badawcza oraz przedmiot badań, tendencje w metodyce badań oraz wybór terenu badań i metody doboru próby badawczej. Strukturę dalszej części artykułu wyznaczają właśnie te wymienione zagadnienia.

\section{Tematyczne kierunki badań naukowych wśród kuratorów sądowych i z ich udziałem}

Analiza zawartości artykułów pozwoliła wyodrębnić następujące obszary tematyczne: trudności, problemy, wypalenie, stres w pracy kuratorów sądowych (15 opracowań); efektywność i poczucie sprawstwa wśród kuratorów (11 opracowań); relacje kuratorów z podopiecznymi (6 opracowań); kompetencje zawodowe, zasoby osobiste i cechy osobowości kuratorów (3 opracowania); warunki, w jakich pracują kuratorzy (8 opracowań); kurator w systemie profilaktyki i resocjalizacji (14 opracowań). Zaznaczam, że liczba wyodrębnionych przeze mnie obszarów jest większa niż 44 (tj. liczba wszystkich prac, jakie analizowałam), ponieważ w niektórych opracowaniach podejmowane były 2-3 zagadnienia na raz.

Badania poświęcone problematyce trudności, wypalenia i stresu zawodowego kuratorów sądowych stanowią dominujący obszar pod kątem frekwencji badań prezentowanych w analizowanych pracach. Te trzy zagadnienia (trudności, wypalenie i stres) włączam do jednej grupy tematycznej, ponieważ zagadnienia te zwykle współwystępowały w podejmowanych analizach. I tak w ich obrębie autorzy badań poszukiwali odpowiedzi na pytanie o uwarunkowania bezpieczeństwa pracy kuratora (Hołyst, Wojtera 2013) oraz o to, na ile czują się bezpiecznie, wykonując swoje obowiązki zawodowe (Janus-Dębska, Gronkiewicz-Ostaszewska 2016). Wyniki badań Brunona Hołysta i Eweliny Wojtery (2013) ukazały, jakich sytuacji stresujących najczęściej doświadczają kuratorzy. Co zaskakujące, okazało się, że przyjmują one nie tylko postać potencjalnych zagrożeń, ale i bezpośrednich ataków agresji fizycznej wobec kuratorów. Doniesienia te znajdują swoje potwierdzenie także w innych pracach. Anna Janus-Dębska i Małgorzata Gronkiewicz-Ostaszewska (2016) ustaliły, że kuratorzy sądowi nie czują się bezpiecznie w swojej pracy i zaledwie niewielki procent z nich nie doświadcza stresu wynikającego z poczucia zagrożenia. Badaczki wymieniły sytuacje niebezpieczne w pracy terenowej kuratora sądowego. Zaliczyły do nich nie tylko związane z demoralizacją podopiecznych, ale również z brudem i skrajnym zaniedbaniem miejsca. Aleksander Cywiński z kolei (2018) również identyfikował właściwości, zwłaszcza pracy w terenie, które sprawiają określone problemy lub trudności, z jakimi musi się zmierzyć kurator sądowy. Obok brudu i skrajnego zaniedbania oraz ubóstwa wymieniał także stan psychiczny podopiecznych. 
Z kolei Anna Janus-Dębska (2016) przeprowadziła badania, w których między innymi ukazała, jakie zadania kuratorzy sądowi określają jako najtrudniejsze w swojej pracy. Były to: współpraca z podopiecznym negatywnie lub roszczeniowo nastawionym do decyzji sądu, dylemat niesienia pomocy przy jednoczesnym egzekwowaniu orzeczeń sądu, tworzenie planu resocjalizacyjnego dla wielokrotnego podopiecznego (Janus-Dębska 2016). Beata Górnicka (2016) natomiast badaniem objęła wyłącznie kuratorów rodzinnych, a także wyodrębniła czynniki, które utrudniają im współpracę z rodzinami. Należało do nich przede wszystkim pejoratywne nastawienie do kuratora sprawującego nadzór w rodzinie i podejmowanych przez niego czynności. Jej ustalenia w zakresie uwarunkowań trudności doświadczanych w pracy przez kuratorów sądowych są spójne z wynikami Janus-Dębskiej (2016). W podobnej konwencji i obszarze tematycznym utrzymane są badania Ewy Kiliszek (2008). Jej ustalenia jednak nieco różnią się od powyżej zasygnalizowanych. Najwięcej badanych przez nią kuratorów wskazało na trudności, jakimi są niewydolność życiowa członków rodzin, problem z uzależnieniami (głównie od alkoholu i narkotyków) oraz słabsza kondycja członków rodzin w zakresie potencjału intelektualnego, zdrowia psychicznego lub fizycznego (Kiliszek 2008).

Tematyką trudności towarzyszących pracy kuratorów sądowych zajmował się także Łukasz Kwadrans (2013) w kontekście efektywności oddziaływań resocjalizacyjnych kuratorów sądowych. Ustalenia Kwadransa rzucają nowe światło na opisywany wymiar pracy kuratora. W opinii kuratorów biorących udział w badaniach najbardziej problematyczne jest nadmierne obciążenie orzeczeniami, brak współpracy ze strony podopiecznych oraz rosnąca biurokratyzacja zadań kuratora (Kwadrans 2013).

Warto również odnieść się do publikacji autorstwa Anny Sajdak (2017), która w badaniach nad rolą kuratora w oddziaływaniach wobec ucznia wagarującego ukazała specyfikę trudności spraw obejmujących pracę z dzieckiem zagrożonym demoralizacją. Kuratorzy w swoich opiniach narzekali na brak motywacji do pracy nad sobą u podopiecznych oraz problem tkwiący w funkcjonowaniu struktury sądu (biurokracja, duża ilość orzeczeń, niskie zarobki) (Sajdak 2017). Wyniki tych badań korespondują z wcześniej prezentowanymi.

Ciekawych wniosków dostarczają badania Ewy Wysockiej (2011) dotyczące świadomości diagnostycznej kuratorów zawodowych dla dorosłych. Autorka ujęła również między innymi problemy, jakie pojawiają się przy realizowaniu czynności diagnostycznych przez kuratorów w ich opinii. Większość osób biorących udział w badaniach wskazało na niedoskonały system prawno-administracyjny oraz zbyt dużą liczbę dozorów (Wysocka 2011).

W 2010 r. opublikowano również pracę dotyczącą kurateli sądowej w Polsce (Wójcik 2010), w której oprócz ukazania oceny kuratorów dotyczącej systemu probacji, ich przekonań o skuteczności wykonywanych przez nich obowiązków zawodowych, przedstawiono także rozważania nad problemami sygnalizowanymi 
przez kuratorów, które występują w ich pracy. Dotyczyły one warunków lokalowych, problemów organizacyjnych, technicznych, jak i poczucia zagrożenia doświadczanego przez kuratorów ze strony nadzorowanych i dozorowanych.

W omawianej grupie tematycznej relatywnie dużo miejsca zajmuje analizowanie sytuacji zawodowej kuratora sądowego przez pryzmat stresu, jakiego doświadcza (5 opracowań). I tak, Bartłomiej Skowroński (2013) opracował inwentarz źródeł stresu w zawodzie kuratora wykorzystywany do diagnozy obszarów stresu, którego doświadczają. Dodam, że w innej swojej pracy (Skowroński 2015) określił źródła stresu w pracy sądowych kuratorów zawodowych, wykonujących orzeczenia w sprawach karnych i nieletnich. Z jego doniesień wynika, że do szczególnych czynników stresogennych należą: relacje między pracownikami oraz podopiecznymi, niewłaściwe wsparcie merytoryczne, utrudnienia stojące na drodze rozwoju kariery, niemożność wypowiedzi dotyczących rozwiązań systemowych oraz niewłaściwe warunki fizyczne w pracy. Łukasz Wirkus (2015) między innymi przeanalizował strukturę poczucia stresu doświadczanego przez kuratorów stresu w odniesieniu do zmiennych organizacyjnych i socjodemograficznych, czynniki ryzyka stresu w pracy kuratorów, ich stan zdrowia, a także zespół wypalenia zawodowego.

Skowroński (2016) podjął również problematykę wypalenia zawodowego wśród kuratorów sądowych. Wyniki jego badań wykazały, że zjawisko to dotyczy prawie połowy kuratorów sądowych z przebadanych przez niego 300 osób. Stres w pracy kuratora sądowego $\mathrm{z}$ wypaleniem zawodowym wiązała Agata Sowa (2006). Badaczka ustaliła, że wypalenie zawodowe wśród kuratorów ma związek ze stresem, złymi warunkami pracy, które wynikają ze zbyt dużej ilości realizowanych dozorów oraz zbiurokratyzowanych procedur (Sowa 2006).

Kolejny obszar tematyczny stanowią dociekania, które można zakwalifikować do kategorii efektywności i poczucia sprawstwa wśród kuratorów. I tak, wyniki badań Beaty Nowak (2010) pozwalają sądzić, że na warunki efektywnej pracy kuratorów sądowych składają się: predyspozycje osobowościowe, orientacja profesjonalna, kompetencje zawodowe, czynniki prawno-organizacyjne oraz społeczno-środowiskowe (Nowak 2010). Należy jednak dodać, że w przedstawionych badaniach brali udział rodzice młodzieży nadzorowanej i ustalenia dotyczące warunków efektywności pracy kuratorów obejmują wyłącznie ich perspektywę. Ta sama autorka podjęła również badania nad skutecznością oddziaływań resocjalizacyjnych z perspektywy samych kuratorów sądowych. Sądowi kuratorzy rodzinni, biorący udział w badaniach, poddali subiektywnej ocenie własne oddziaływania o charakterze wychowawczym. Wyniki tych badań pokazały, że znacząca liczba kuratorów sądowych ocenia wydajność swoich oddziaływań resocjalizacyjnych jako niewielką, głównie ze względu na ich niesystematyczność i doraźność (Nowak 2011). Andrzej Węgliński (2008) również podjął problematykę skuteczności oddziaływań wychowawczych przez kuratorów rodzinnych. Podobnie jak Nowak (2011), tak i on w swoich badaniach przeanalizował autopercepcję sposobów 
oddziaływań wychowawczych społecznych kuratorów sądowych pod kątem uwarunkowań efektywności. Między innymi kuratorzy społeczni mieli szansę ocenić swoje poczucie sukcesu w pracy z podopiecznymi. Badania te pokazały, że miarą sukcesu zawodowego jest udana adaptacja społeczna podopiecznych oraz brak powrotu do przestępczości (Węgliński 2016).

Anna Witkowska-Peleń (2008), z kolei, w swoich badaniach odniosła się do skuteczności pracy społecznych kuratorów sądowych. Przeanalizowała opinie zawodowych kuratorów sądowych na temat instytucji społecznego kuratora sądowego (Witkowska-Peleń 2008). Tak samo jak Krzysztof Gogacz (2012) Witkowska-Peleń (2008) wskazała na determinanty efektywności pracy kuratorów w ich ocenie. Badani wymieniali głównie, oprócz doświadczenia życiowego i pomocy, jaka jest udzielana podopiecznym, zdolności komunikacyjne, empatię oraz umiejętność nawiązywania współpracy z innymi instytucjami o charakterze profilaktyczno-prewencyjnym (Witkowska-Peleń 2008; Gogacz 2012).

Podobną problematyką badawczą zajmowali się Tadeusz Jedynak, Andrzej Rzepniewski, Henryk Pawlaczyk (2005), którzy stworzyli raport pt. „Raport dotyczący oceny efektywności kuratorskiej służby sądowej oraz oceny kosztów jej funkcjonowania i szacunkowych kosztów zwiększenia jej efektywności", w którym została podjęta próba oszacowania skuteczności działań kuratorskiej służby sądowej. Kryterium oceny w przypadku kuratorów wykonujących orzeczenia w sprawach karnych stanowiła liczba prowadzonych przez kuratorów spraw oraz liczba osób, wobec których postępowanie wykonawcze zostało zakończone (w warunkach probacji lub izolacji). W przypadku kuratorów rodzinnych kryterium oceny stanowiła liczba wykonanych wywiadów środowiskowych oraz liczba nadzorów kuratorskich. W obu przypadkach ocena pracy została określona jako pozytywna, ponieważ nastąpił wzrost wykonywanych spraw przez kuratorów oraz liczba osób, wobec których sprawy zostały zakończone. Nastąpił również wzrost wykonywanych wywiadów środowiskowych oraz nadzorów kuratorskich (Jedynak, Rzepniewski, Pawlaczyk 2005).

Przejawem efektywności pracy kuratora, a na pewno poczucia sprawstwa jest odczuwany poziom satysfakcji ze swoich działań i ich skutków. Do poczucia satysfakcji kuratorów z wykonywanych obowiązków odniosła się również Janus-Dębska (2016). Co ciekawe, mimo problemów, jakich doświadczają kuratorzy sądowi, większość z nich (a przynajmniej osób biorących udział w sygnalizowanych badaniach) deklarowała odczuwanie satysfakcji z wykonywanej pracy. Autorka zwróciła uwagę, że w pracy kuratora efekty nie są natychmiastowe i często widoczne są dopiero po długim okresie pracy z podopiecznymi. Świadomość tego, że „skuteczność" w resocjalizacji jest trudna do szacowania, ponieważ czasem ujawnia się dopiero po latach, pozwala kuratorom na doświadczanie poczucia sprawczości (Janus-Dębska 2016). Natomiast Ewa Grudziewska (2017) w swoich badaniach nad satysfakcją z pracy kuratorów sądowych wskazała na takie czynniki determinujące, jak: zmienne socjodemograficzne, zmienne powiązane $\mathrm{z}$ zasobami osobistymi, 
a także organizacją pracy. Badaczka zaznaczyła również, że istnieje potrzeba sprawdzenia, czy satysfakcja z pracy kuratorów sądowych ma związek z relacjami z podopiecznymi, współpracownikami, a także nadmierną biurokratyzacją (Grudziewska 2017).

Problematyką tą zajęła się także Górnicka (2016). W jej badaniach kuratorzy rodzinni w swoich opiniach poddawali ocenie własną efektywność współpracy z rodzinami i szkołami nieletnich, nad którymi sprawują dozór. Analiza wyników pozwoliła stwierdzić jedynie tyle, że w opinii większości kuratorów rodzinnych te rodzaje współpracy są efektywne (Górnicka 2016). O efektywności w oddziaływaniach profilaktycznych kuratorów rodzinnych pisała również Beata Zinkiewicz (2015). W odczuciu kuratorów biorących udział w jej badaniach efektywność tych działań jest niewielka ze względu na specyfikę problemów, z jakimi borykają się rodziny (Zinkiewicz 2015).

Kolejną pulę problemów badawczych podejmowanych przez badaczy stanowią relacje kuratorów sądowych z podopiecznymi.

Górnicka (2016) analizuje relacje kuratorów rodzinnych z nieletnimi podopiecznymi i ich rodzinami w kontekście nie tylko czynności nadzorowania i sprawowania kontroli, ale także udzielania porad dotyczących opieki lub wychowania, wsparcia psychicznego lub informacji. W sygnalizowanych badaniach kuratorzy rodzinni określali, jak według nich układa się współpraca z rodzinami w wymienionych orzeczeniach. Ich oceny ograniczały się jednakże tylko do pozytywnej lub negatywnej oceny (Górnicka 2016) i w większości opinii kuratorów rodzinnych była ona dobra.

Andrzej Węgliński (2016) w swoich badaniach uwzględnił również to, w jaki sposób sądowi kuratorzy społeczni określają swoją pracę z podopiecznymi. W ich opinii jest ona głównie oparta na relacji i modelu „wychowującym”. Kuratorzy do swoich zobowiązań zawodowych włączali zaangażowanie i pomoc udzielaną podopiecznym, dbałość o dobre kontakty z rodziną i dozorowanym (Węgliński 2016). Natomiast przywołane już wcześniej przeze mnie badania Cywińskiego (2018) nad wzajemnymi społecznymi reprezentacjami kuratorów sądowych dla dorosłych oraz ich podopiecznych pozwoliły mu między innymi wyłonić treści tych reprezentacji społecznych, które odnoszą się do relacji. Na charakter oraz treść tych relacji zdaniem Cywińskiego składa się chęć współpracy podopiecznego z kuratorem (współpracujący/niewspółpracujący) oraz preferowanie miejsca pracy przez kuratora (w terenie vs. w sądzie) (Cywiński 2018).

Do zagadnienia relacji między kuratorami i podopiecznymi odniósł się także w swoich badaniach Piotr Stępniak (2010) w opracowaniu, w którym przedstawił modele pracy kuratorów sądowych po wprowadzeniu zmian w ustawodawstwie polskim w roku 2001. Stworzona przez niego typologia modeli wykonywania nadzorów przez kuratorów zawodowych i społecznych nawiązywała przede wszystkim do charakteru relacji, jakie się tworzą w procesie dozorowania/nadzo- 
rowania. Wymienił model kurateli sądowej (zawodowej i społecznej), wychowujący, kontrolny, administracyjno-biurowy oraz pomocowy, w oparciu o czynności i rodzaj współpracy kuratorów z podopiecznymi, których realizację deklarowali kuratorzy biorący udział w badaniach (Stępniak 2010).

Ciekawe ujęcie relacji, jakie tworzą kuratorzy sądowi ze swoimi podopiecznymi, przedstawiła także Nowak (2011). Według niej to wykształcenie kierunkowe ma znaczenie dla jakości pracy kuratorskiej, w tym relacji międzyosobowych, w jakie wchodzi z podopiecznym. I tak według jej ustaleń można mówić o pewnych tendencjach: kuratorzy pedagodzy wykorzystują perswazję i metodę wpływu osobistego, socjologowie analizują zachowanie i kierunki zmiany w postępowaniu podopiecznych, a u prawników relacja oparta jest na kontroli oraz monitorowaniu pracy podopiecznych (Nowak 2011).

Na zakończenie tego wątku warto przytoczyć badania Anny Chmielewskiej (2014), które dostarczają ciekawych wniosków na rzecz warunków budowania relacji między kuratorami i podopiecznymi. We wnioskach z badań, jakie zrealizowała za pomocą wywiadów przeprowadzonych $\mathrm{z}$ podopiecznymi kuratorów wykonujących orzeczenia w sprawach karnych i rodzinnych, pokazała pewien dualizm roli kuratora. Z jednej strony kurator pełni rolę doradcy, powiernika, osoby godnej zaufania, a z drugiej strony jest przedstawicielem sądu (Chmielewska 2014).

Chociaż kompetencje zawodowe, zasoby osobiste i cechy osobowości stanowią wyraźnie wyłoniony obszar tematyczny badań nad kuratelą sądową w Polsce, to nie stanowią znaczącej ilości wśród ogółu badań. Katarzyna Nanowska (2016) przeprowadziła wywiady z kuratorami okręgowymi dotyczące tego, w jaki sposób jest realizowany proces kształcenia przyszłych kuratorów. Badaczka poszukiwała odpowiedzi na pytania o zalety istniejącego modelu kształcenia kompetencji kuratorów oraz trudności w jego realizacji. Badani zwrócili uwagę na potrzebę rozwijania szczególnie ważnych kompetencji w pracy kuratorów sądowych, takich jak: rozwiązywanie problemów, podejście do ludzi i umiejętności komunikacyjne (Nanowska 2016).

Ewa Kiliszek (2016), prowadząc badania kwestionariuszowe dotyczące zasobów osobistych i społecznych kuratorów sądowych, dowiodła, że kuratorzy sądowi stosują styl radzenia sobie ze stresem skoncentrowany na zadaniu, a ich poczucie koherencji głównie zaznacza się w poczuciu zrozumiałości (poznawcza ocena rzeczywistości) i zaradności, mniej w poczuciu sensowności. Co więcej, styl radzenia sobie ze stresem wśród kuratorów sądowych występuje w istotnej korelacji z poczuciem koherencji (Kiliszek 2016). We wspomnianych już badaniach z udziałem rodziców młodzieży nadzorowanej Nowak (2010) wyszczególniła cechy kuratorów sądowych, które znajdują się wśród oczekiwań rodzin i są to życzliwość, cierpliwość, otwartość, a także zaradność (zdolność do rozwiązywania trudności życiowych). Natomiast umiejętności dotyczyły głównie komunikowania się (Nowak 2010). Dodam, że w badaniach tych wskazano na oczekiwania, jakie stawiane są 
przed osobami podejmującymi zawód kuratora, a które zdecydowanie wpisują się w oddziaływania o charakterze pomocowym.

Warunki, w jakich pracują kuratorzy, rozumiane jako organizacja i przebieg jego pracy w tzw. terenie, stanowią kolejną problematykę wśród badań dotyczących kurateli sądowej w Polsce. 0 warunkach pracy kuratorów sądowych pisali badacze, których wyniki badań i prace przywoływałam już wcześniej, na przykład: DębskaJanus, Gronkiewicz-Ostaszewska (2016), Wójcik (2010) czy Nowak (2011). Do warunków pracy kuratora odnosił się również Cywiński (2018) podczas opisu trudności i problemów pojawiających się podczas realizacji zadań przez kuratora (por. Wirkus 2015; Skowroński 2015). Z publikacji, jakie analizowałam, wyłoniłam poniżej opracowania, które można wpisać wyłącznie w ten obszar tematyczny.

I tak na korelację jakości życia i pracy kuratorów sądowych wskazali w swoich badaniach Łukasz Wirkus i Krzysztof Stasiak (2018). Wyniki ich badań pokazały między innymi, że pomimo specyfiki wykonywanych przez nich czynności zawodowych i warunków pracy w terenie są na ogół zadowoleni ze swojej pracy. Ciekawe jest również to, że niezależnie od trudności wynikających z charakteru pracy terenowej zdecydowana większość kuratorów sądowych woli realizować czynności w środowisku życia podopiecznych niż w sądzie (Wirkus, Stasiak 2018).

Katarzyna Jadach (2011) prowadziła badania nad rekonstrukcją realnego modelu pracy kuratorów sądowych. Autorka uwzględniła również ocenę warunków, $\mathrm{w}$ jakich pracują kuratorzy w ich opinii. Skonfrontowała normatywny model pracy z realnym i przedstawiła propozycje zmian w organizacji pracy kuratorów sądowych (Jadach 2011).

Wreszcie ostatni obszar badań nad kuratelą sądową w Polsce, który wyróżniłam, skupia się wokół oddziaływań wpisanych przez ustawodawstwo w zakres zadań kuratorów sądowych (Dz.U. z 2001 r., Nr 98, poz. 1071). W większości wymienionych przeze mnie badań można wyszczególnić problematykę dotyczącą zadań kuratorów sądowych o charakterze wychowawczo-resocjalizacyjnym i profilaktycznym. Badania w tym zakresie znaleźć można w publikacjach, które opisałam już wcześniej: Chmielewskiej (2014), Wójcik (2010), Stępniaka (2010), Gogacza (2012), Kwadransa (2011) czy Węglińskiego (2008). Także Nowak (2011) w swoich badaniach nad skutecznością oddziaływań kuratorów sądowych odniosła się do tych o charakterze resocjalizacyjnym. Natomiast Węgliński (2016), poddając analizie oddziaływania wychowawcze społecznych kuratorów sądowych (w tym pedagogów resocjalizacyjnych), zbadał sposoby ich definiowania przez kuratorów. Okazało się, że według nich jest to rola wychowawcy, powiernika, opiekuna i nauczyciela. Dowodzi to tego, że utożsamiają działania kuratorów z szeroko pojętym wychowaniem (Węgliński 2016). Warto wspomnieć, że Węgliński (2013) podejmował wiele problemów z obszaru pracy kuratora sądowego w kontekście profilaktyki i resocjalizacji. Poddał także analizie pracę kuratorów w ośrodkach kuratorskich. 
Do zadań kuratora sądowego odniosła się również w swoich badaniach Martyna Sajdak (2017). Co prawda, w oddziaływaniach wobec ucznia wagarującego skupiła się między innymi na metodach pracy z uczniem wagarującym, jakie kuratorzy stosują, a także trudnościach, na jakie napotykają, ale za punkt wyjścia uczyniła pytanie o znaczenie i rolę, jaką odgrywa kurator sądowy w postępowaniu z dzieckiem wagarującym. Sformułowała także hipotezę, że kuratorzy pełnią rolę doradcy i pomocnika. Wyniki badań nie były szczególnie poznawcze, bowiem badaczka ustaliła, że kuratorzy biorący udział w tych badaniach wskazali, że stosują metodę indywidualnego przypadku (case work), ponieważ zapewnia kompleksowe oddziaływania wychowawcze i pomaga kuratorowi w nawiązaniu lepszego kontaktu z podopiecznym (Sajdak 2017).

Pomimo tego, że częściej opracowania empiryczne dotyczą oddziaływań resocjalizacyjnych, to można znaleźć również poświęcone profilaktyce, na przykład, we wspomnianych wcześniej badaniach Zinkiewicz (2015) na temat oddziaływań zapobiegawczych realizowanych przez rodzinnych kuratorów sądowych. Autorka podjęła próbę diagnozy czynności realizowanych przez kuratorów rodzinnych wobec nadzorowanych rodzin o charakterze profilaktycznym i prewencyjnym. Okazało się, że zdecydowanie wybija się model kontrolny sprawowania nadzoru, pomimo że postulowany jest opiekuńczo-terapeutyczny (Zinkiewicz 2015). Zajęła się tym także Aneta Gasińska (2017). Dokonała diagnozy sytuacji podopiecznych kuratorów, a następnie zaprosiła do udziału w badaniach samych kuratorów rodzinnych. Badania te potwierdziły korzystanie przez kuratorów rodzinnych metody indywidualnych przypadków (case work) w stosunku do nieletnich nadzorowanych (tamże).

Należy wspomnieć o pracy Andrzeja Bałandynowicza (2007), który między innymi analizował działania kuratorów sądowych na rzecz readaptacji osób przebywających w zakładzie karnym. Przedstawiał między innymi etapy pracy kuratora z dozorowanym podczas interwencji kryzysowych, oddziaływań długoterminowych i współpracy z rodziną dozorowanego (Bałandynowicz 2007). Natomiast Kamil Konopka prowadził badania, w których ukazał, jak oddziałują kuratorzy sądowi na życie rodziny podopiecznego. Ciekawe w jego analizie było to, że podawał przykłady sytuacji, w których kuratorzy podejmowali działania o charakterze wychowawczo-resocjalizacyjnym (Konopka 2012).

Jest również wiele opracowań prezentujących wyniki badań głównie sondażowych bądź opartych na analizach dokumentów (akt wykonawczych), które przedstawiają aktualny stan prawny i realny obraz realizowania zadań przez kuratorów. Takie prace czasami są zlecane przez Biuro Rzecznika Praw Obywatelskich i przeważnie przyjmują formę raportów (zob. Mazur 2008; Kazimirski, Kuźma 2008; Zagórski 2008; Bulenda, Musidłowski 2008; Michelis 2008; Kiryluk 2008). 


\section{Dominujące metody oraz organizacja badań z udziałem kuratorów sądowych}

Wśród analizowanych badań dominują badania normatywne, o charakterze ilościowym (39 z ogółu 44). Przeważająca liczba przytoczonych przeze mnie badań stanowi analizę danych zebranych przy wykorzystaniu sondażu diagnostycznego, na przykład Wysocka (2011), Górnicka (2016), Nowak (2011).

W większości wnioski sformułowane przez badaczy są oparte na wynikach badań opinii samych kuratorów, na przykład Skowroński (2016), Hołyst, Wojtera (2013), Janus-Dębska, Gronkiewicz-Ostaszewska (2016), Witkowska-Paleń (2008) oraz ich podopiecznych (zob. Nowak 2010; Mazur 2008; Bulenda, Musidłowski 2008). Czasami w badaniach dochodzi do połączenia metod i wtedy zwykle stosowana jest analiza dokumentów oraz sondaż diagnostyczny (zob. Kazimirski, Kuźma 2008; Zinkiewicz 2015).

Wielkość prób badawczych była zróżnicowana, wynosiły od kilkuset (zob. Stępniak 2010; Skowroński 2016) do kilkudziesięciu osób biorących udział w badaniach (zob. Grudziewska 2017; Wirkus, Stasiak 2018; Kiliszek 2016). Badania realizowane są w całej Polsce (zob. Skowroński 2016; Zagórski 2008), w poszczególnych okręgach lub miastach (zob. Gąsińska 2017; Wirkus, Stasiak 2018) lub czasami w wybranych sądach rejonowych (zob. Kiliszek 2011). Stąd próby badawcze były dobierane w sposób celowy i losowy w zależności od problematyki i celu badań. Pojawiają się również badania, w których wykorzystywane są gotowe narzędzia psychometryczne (zob. Kiliszek 2016; Wirkus, Stasiak 2018) lub opracowane przez autora badań, jak w przypadku inwentarza źródeł stresu stworzonego przez Skowrońskiego $(2013,2015)$.

Niewątpliwie badania o charakterze jakościowym nad kuratelą sądową w Polsce stanowią mniejszość. Najczęściej przeprowadzane są wywiady swobodne (zob. Cywiński 2018; Nanowska 2016; Chmielewska 2014), ale również są badania, w których dodatkowo stosuje się analizę dokumentów i obserwację (zob. Wójcik 2010). Badacze wykorzystują tylko jedną perspektywę poznawczą, na przykład badania samych kuratorów (zob. Nanowska 2016), lub dwie na raz, na przykład badania kuratorów i podopiecznych (zob. Cywiński 2018). Znalazły się również badania, które mimo że są zorientowane jakościowo, to w analizie danych pojawiają się zestawienia procentowe (zob. Chmielewska 2014). Uwagę zwraca to, że prace, w których wykorzystano metodę obserwacji należą do wyjątku (zob. Wójcik 2010).

Wykorzystywane metody badań są słabo zróżnicowane. Dominują badania ankietowe. Wśród jakościowych zaś dominującym sposobem gromadzenia danych są wywiady swobodne. Szczególną uwagę zwraca to, że badania dotyczące kuratorów sądowych zdecydowanie utrzymane są w nurcie badań pozytywistycznych. Znalazłam nieliczne wyjątki prac empirycznych (zob. Cywiński 2018), których teoretyczno-metodologiczne założenia mieszczą się w paradygmacie interpretatywnym. 
Uwagę zwraca to, że metoda case study jest popularna w metodyce postępowania kuratora sądowego, zaś właściwie nieobecna w praktyce badań empirycznych. Nie znalazłam badań z wykorzystaniem studium przypadku, jak również metody biograficznej, które bez wątpienia pozwoliłyby wniknąć w świat społeczno-zawodowy kuratorów sądowych, tj. poznać i zrozumieć proces resocjalizacji pozainstytucjonalnej w naturalnym środowisku ich podopiecznych.

\section{Podsumowanie}

Co prawda, pobieżna analiza zasobów internetowych pozwala sądzić, że problematyka kurateli sądowej w Polsce stanowi znaczące pole zainteresowań w polskim dyskursie naukowym. Kiedy jednak uważniej wniknie się w zawartość wielu prac, okazuje się, że znaczna ich część to analizy normatywne (np. przegląd aktów prawnych i ich interpretacja pod kątem pracy kuratora sądowego).

Oczywiście dostępne są prace o charakterze empirycznym, ale ich analiza wykazała, że dominują badania o charakterze ilościowym (sondażowym, z udziałem niewielkiej grupy badanych). Metody badań jakościowych rzadko są wykorzystywane przez badaczy tej problematyki.

Zdecydowana większość wniosków dostarczanych przez badaczy została opracowana $\mathrm{w}$ oparciu o dane pochodzące $\mathrm{z}$ badania opinii i deklaracji kuratorów sądowych na temat tego, jak wygląda ich praca. Zdarzają się analizy, w których są zestawiane stanowiska kuratorów sądowych ze zdaniem ich podopiecznych (ale konfrontacji takich jest niewiele). Można więc sformułować wniosek, że głównie są to badania o pracy zawodowej kuratora sądowego, pochodzące z danych dostarczanych przez samych kuratorów sądowych.

Jeśli chodzi o problematykę realizowanych badań nad kuratelą sądową w Polsce po roku 2001, to najchętniej podejmowanym obszarem tematycznym przez badaczy są trudności i problemy, na jakie natyka kurator sądowy w swojej pracy zawodowej, oraz wiążące się z nimi poczucie sprawczości i efektywność resocjalizacyjna. Jeśli chodzi o trudności, to badacze opisują te, które tkwią w organizacji pracy (np. sztywne ramy prawne, rozbudowana biurokratyzacja) oraz które związane są z właściwościami i kondycją psychospołeczną swoich podopiecznych (kondycja psychiczna, agresywność, uzależnienia), a także środowiskiem ich życia (ubóstwo, brud).

Co do organizacji i terenu badań, to uwagę zwraca to, że można znaleźć wiele projektów lokalnych, w których biorą udział kuratorzy z danego miasta lub sądu. Badań, które mają lokalny charakter (np. dotyczą pracy kuratorów z jednego sądu, miasta czy okręgu), jest zdecydowanie więcej. Niewiele jest opracowań empirycznych, gdzie prezentowane są badania na dużej próbie badawczej, nawet jeśli mają one szeroki zasięg i nie są lokalne. Nie oznacza to jednak, że takich badań nie ma, czego przykładem są prace Skowrońskiego (2016) czy Stępniaka (2010). 
Na zakończenie pragnę podkreślić, że zdaję sobie sprawę z tego, że lista opracowań, którą przedstawiłam i które poddałam analizie nie jest zamknięta. Jestem świadoma ograniczeń związanych z brakiem wielu publikacji w zasobach internetowych. Można więc uznać, że przedstawione przeze mnie prace ujawniają wyłącznie dominujące tendencje oraz pozwalają zasygnalizować pewne luki we współcześnie prowadzonych badaniach nad kuratelą sądową w Polsce.

\section{Bibliografia}

Bałandynowicz A. (2007) Kuratela dla dorosłych - pomoc w przystosowaniu do życia w społeczeństwie, „Prawo i Prokuratura”, nr 9, s. 5-28.

Bałandynowicz A. (2011) Probacja. Resocjalizacja z udziałem społeczeństwa, Warszawa, Wolters Kluwer Polska SA.

Bulenda T., Musidłowski R. (2008) Dozór kuratora sq̨dowego przy warunkowym zwolnieniu w: Wykonywanie środków probacji i readaptacji skazanych w Polsce, J. Zagórski (red.), Warszawa, Biuro Rzecznika Praw Obywatelskich, s. 139-176.

Bulenda T., Musidłowski R. (2008) Wykonywanie dozoru orzeczonego na wniosek skazanego - readaptacja społeczna skazanego na podstawie art $167 \mathrm{kkw}$ w: Wykonywanie środków probacji i readaptacji skazanych w Polsce, J. Zagórski (red.), Warszawa, Biuro Rzecznika Praw Obywatelskich, s. 227-261.

Chmielewska A. (2014) Rola kuratora sq̨dowego w relacji z dozorowanymi-sprawcami przestępstwa, „Probacja”, nr 1, s. 63-79.

Cywiński A. (2018) Wzajemne społeczne reprezentacje zawodowych kuratorów sądowych do spraw dorosłych i ich podopiecznych, Warszawa, Oficyna Wydawnicza „Impuls”.

Gąsińska A. (2017) Oddziaływania kuratora sq̨dowego wobec nieletnich niedostosowanych społecznie, „Forum Pedagogiczne”, nr 1, s. 279-289.

Gogacz K. (2012) Różnicowanie oddziaływań resocjalizacyjnych społecznych kuratorów sq̨dowych a efektywność dozorów probacyjnych, Radom, Wyższa Szkoła Handlowa.

Gogacz K. (2015) Kurator sądowy wobec wyzwań i zagrożeń resocjalizacji skazanych w środowisku otwartym, „Journal of Modern Science”, nr 24.1, s. 131-147.

Górnicka B. (2016) Współpraca z podopiecznymi, ich rodzinq i szkołq w opiniach rodzinnych kuratorów sq̨dowych, „Resocjalizacja Polska”, nr 12, s. 217-237. 
Gromek K. (2001), Probacja czy kuratela albo środki alternatywne - próba optymalizacji systemu w ujęciu ewolucyjnym w: Probacyjne środki polityki karnej - stan i perspektywy, B. Cichońska i in. (red.), Warszawa, Dział Wydawniczy Kancelarii Senatu.

Grudziewska E. (2017) Satysfakcja z pracy kuratorów sq̨dowych - komunikat z badań, „Niepełnosprawność", nr 28, s. 222-232.

Hołyst B., Wojtera E. (2013), Bezpieczeństwo kuratorów sq̨dowych w świetle badań ogólnopolskich, Warszawa, Wyższa Szkoła Administracyjno-Społeczna w Warszawie.

Jadach K. (2011) Praca kuratora sq̨dowego w sprawach rodzinnych, nieletnich i karnych, Poznań, Wydawnictwo Naukowe Uniwersytetu im. Adama Mickiewicza.

Janus-Dębska A. (2016) Dylematy w pracy kuratora sq̨dowego $w$ świetle badań własnych, cz. I, „Probacja”, nr 6, s. 49-76.

Janus-Dębska A. (2016) Dylematy w pracy kuratora sq̨dowego w świetle badań własnych, cz. II, „Probacja”, nr 8, s. 79-112.

Janus-Dębska A., Gronkiewicz-Ostaszewska M. (2016) Bezpieczeństwo kuratorów sqdowych $w$ świetle badania ankietowanego, Warszawa, Instytut Wymiaru Sprawiedliwości.

Jedynak T., Rzepniewski A., Pawlaczyk H. (2005) Raport dotyczq̨cy oceny efektywności kuratorskiej służby sq̨dowej oraz oceny kosztów jej funkcjonowania i szacunkowych kosztów zwiększenia jej efektywności, http://kurator.webd.pl/pliki/pliki/raport.doc

Jedynak T., Stasiak K. (2008) Zarys metodyki pracy kuratora sq̨dowego, Warszawa, Wydawnictwo Prawnicze LexisNexis.

Jurczyk D., Staniucha A. (2015) Wspótpraca kuratorów sądowych z innymi służbami w realizowaniu zadań profilaktyczno-resocjalizacyjnych, „Resocjalizacja Polska”, nr 10, s. 111-123.

Kazimirski P., Kuźma Z. (2008) Wykonywanie orzeczeń o warunkowym umorzeniu postępowania karnego w: Wykonywanie środków probacji i readaptacji skazanych $w$ Polsce, J. Zagórski (red.), Warszawa, Biuro Rzecznika Praw Obywatelskich, s. $109-138$.

Kępka S. (2007) Kuratela sq̨dowa: wychowująca czy kontrolno-represyjna? Ujęcie formalnoprawne w: Profilaktyka i adaptacja społeczna, E. Bielecka (red.), Białystok, Wydawnictwo Uniwersyteckie Trans Humana.

Kiliszek E. (2011) Rodzina wieloproblemowa $w$ nadzorze sq̨owego kuratora rodzinnego, „Prace Insytutu Profilaktyki Społecznej i Resocjalizacji Uniwersytetu Warszawskiego", t. 17, s. 255-284. 
Kiliszek E. (2016) Zasoby osobiste i społeczne sq̨dowych kuratorów zawodowych na podstawie próby kuratorów zawodowych ze studiów podyplomowych UW IPSIR, „Profilaktyka Społeczna i Resocjalizacja", nr 29, s. 35-63.

Kiryluk M. (2008) Udział kuratora sądowego w przygotowaniu skazanego do życia po zwolnieniu z zakładu karnego w trybie art. 164 kkw w: Wykonywanie środków probacji i readaptacji skazanych $w$ Polsce, J. Zagórski (red.), Warszawa, Biuro Rzecznika Praw Obywatelskich, s. 201-226.

Konopczyński M. (2015) Dwubiegunowość procesu resocjalizacji instytucjonalnej, „Resocjalizacja Polska", nr 10, s. 9-13.

Konopka M. (2012), Wspótczesny wpływ kuratora sq̨dowego na rodzinę podopiecznego w: Instytucja rodziny wczoraj i dziś. Perspektywa interdyscyplinarna, Lublin, Politechnika Lubelska, s. 66-71.

Kusztal J., Muskała M. (2018) Kurator sq̨dowy wobec nowych zadań i zmian w systemie resocjalizacji, „Studia Pedagogica Ignatiana”, nr 21, s. 19-39.

Kwadrans Ł. (2013) Oczekiwane efekty resocjalizacji a rzeczywiste możliwości oddziaływania kuratorów sq̨dowych, „Resocjalizacja Polska”, nr 4, s. 275-287.

Lewicka-Zelent A., Lasota A. (2018) Uczestnictwo kuratora sq̨dowego w kontaktach rodziców z dzieckiem. Wybrane zagadnienia ogólne w świetle projektu kodeksu rodzinnego, „Probacja”, t. I, s. 5-24.

Liszke W. (2009) Przygotowanie skazanego do życia po zwolnieniu z zakładu karnego przez kuratora sq̨dowego, „Probacja”, nr 151, s. 113-122.

Mazur M. (2008) Realizacja orzeczeń o warunkowym zawieszeniu wykonania kary pozbawienia wolności bez oddania skazanego pod dozór w: Wykonywanie środków probacji i readaptacji skazanych w Polsce, J. Zagórski (red.), Warszawa, Biuro Rzecznika Praw Obywatelskich, s. 31-68.

Michel M. (red.) (2011) Streetworking: Aspekty teoretyczne i praktyczne, Kraków, Wydawnictwo Uniwersytetu Jagiellońskiego.

Michelis J. (2008) Orzekanie i wykonywanie przerwy w odbywaniu kary pozbawienia wolności wobec skazanych zobowiq̨zanych do utrzymywania kontaktu z kuratorem sądowym w: Wykonywanie środków probacji i readaptacji skazanych w Polsce, J. Zagórski (red.), Warszawa, Biuro Rzecznika Praw Obywatelskich, s. 177-200.

Nanowska K. (2016) Kompetencje profesjonalne kuratorów sq̨dowych dla dorosłych wobec zmieniającej się rzeczywistości prawnej w perspektywie specjalizacji zawodowej, „Edukacja Humanistyczna”, nr 2/35, s. 135-146. 
Nowak B. (2010), Uwarunkowania skuteczności pracy kuratorskiej, „Szkice Podlaskie”, nr 17-18, s. 291-299.

Nowak B. (2011), Skuteczność oddziaływań resocjalizujących w percepcji kuratorów sądowych w: Tożsamość osobowa dewiantów a ich reintegracja społeczna, A. Kieszkowska (red.), Kraków, Oficyna Wydawnicza „Impuls”, s. 339-350.

Pospiszyl I., Konopczyński M. (red.) (2007), Resocjalizacja - w stronę środowiska otwartego, Warszawa, Wydawnictwo PEDAGOGIUM Wyższej Szkoły Pedagogiki Resocjalizacyjnej.

Sajdak M. (2017) Nadzór kuratora sq̨dowego wobec ucznia wagarującego, „Forum Pedagogiczne", nr 2, s. 327-338.

Sawicki K., Konarzewski K. (red.) (2014) Środowiskowy wymiar niedostosowania. Teorie-badania-praktyka, Białystok, Agencja Wydawnicza „Ekopress”.

Sikora A. (2017) Organizacje pozarzadowe $w$ systemie przeciwdziałania napiętnowaniu wychowanków placówek resocjalizacyjnych w: Naznaczeni odrzucani i dyskryminowani $w$ badaniach naukowych i praktyce wychowawczej ujęcie interdyscyplinarne, P. Dzieduszyński (red.), Łódź, Wydawnictwo Naukowe Wyższej Szkoły Biznesu i Nauk o Zdrowiu, s. 156-169.

Sikora A. (red.) (2015) Program pozytywnej integracji społecznej młodzieży opuszczającej placówki resocjalizacyjne, Warszawa, Fundacja po DRUGIE.

Skowroński B. (2013) Inwentarz źródeł stresu w zawodzie kuratora: opis konstrukcji i własności psychometryczne „Profilaktyka Społeczna i Resocjalizacja”, nr 21, s. 119-140.

Skowroński B. (2015) Stres sq̨dowych kuratorów zawodowych wykonujących orzeczenia w sprawach karnych i nieletnich, „Resocjalizacja Polska”, nr 10, s. 209-227.

Skowroński B. (2016) Wypalenie zawodowe sq̨dowych kuratorów zawodowych wykonujących orzeczenia $w$ sprawach karnych i rodzinnych, „Resocjalizacja Polska”, nr 11, s. 185-209.

Sowa A. (2006) Problem wypalenia zawodowego wśród kuratorów w: Współczesna kuratela sądowa, B. Zinkiewicz (red.), Mysłowice, Wydawnictwo Górnośląskiej Szkoły Wyższej, s. 110-124.

Stępniak P. (2010) Modele kurateli sądowej po roku 2001 w świetle badań empirycznych, „Archiwum kryminologii”, t. XXXII, s. 157-203.

Stępniak P. (2014) Zawieszenie wykonywania kary pozbawienia wolności i dozór kuratora w projekcie nowelizacji prawa karnego, „Przegląd Więziennictwa Polskiego”, nr 83, s. 45-60. 
Szczepanik R., Jaros A., Staniaszek M. (2018) Sąd nad demoralizacjq nieletnich. Konteksty wychowawcze, Łódź, Wydawnictwo Uniwersytetu Łódzkiego.

Szymanowski T. (2003) Działalność kuratorów sądowych w pierwszym pótroczu $2002 \mathrm{r}$. w świetle wyników badań w: Kurator $w$ społeczeństwie obywatelskim, J. Lipski, A. Chodyra (red.), Warszawa, Kancelaria Sejmu, s. 9-41.

Ustawa z dnia 27 lipca 2001 roku o kuratorach sądowych (Dz.U. z 2001 r., $\mathrm{Nr}$ 98, poz. 1071).

Węgliński A. (2008) Skuteczność i jakość oddziaływań wychowawczych w warunkach nadzorów kuratorskich w: Sukcesy i porażki poprawiania niepoprawnych, I. Pospiszyl (red.), Kielce, Wszechnica Świętokrzyska.

Węgliński A. (2008) Tożsamość zawodowa kuratorów rodzinnych a skuteczność oddziaływań resocjalizacyjnych w: Skuteczna resocjalizacja. Doświadczenia i propozycje, Z. Bartkowicz, A. Węgliński (red.), Lublin, Wydawnictwo Uniwersytetu Marii Curie-Skłodowskiej.

Węgliński A. (2013) Pedagogiczne uwarunkowania resocjalizacji nieletnich w ośrodkach kuratorskich w: Efektywność resocjalizacji nieletnich $w$ warunkach wolnościowych, Z. Bartkowicz, A. Wojnarska, A. Węgliński (red.), Lublin, Wydawnictwo Uniwersytetu Marii Curie-Skłodowskiej, s. 11-32.

Węgliński A. (2016) Autopercepcja bezpośrednich oddziaływań wychowawczych społecznych kuratorów sq̨dowych, „Lubelski Rocznik Pedagogiczny", t. XXXV, s. 55-83.

Wirkus Ł. (2015) Stres w pracy kuratora sq̨dowego. Studium teoretyczno-empiryczne, Kraków, Oficyna Wydawnicza „Impuls”.

Wirkus Ł., Stasiak K. (2018) Jakość życia kuratorów sq̨dowych, „Resocjalizacja Polska”, nr 15, s. 195-216.

Witkowska-Paleń A. (2008) Instytucja społecznego kuratora sq̨dowego w opinii osób pełniących funkcję kuratora, Stalowa Wola, Katolicki Uniwersytet Lubelski Jana Pawła II.

Wójcik D. (red.) (2010) Kuratela sądowa: sukcesy i porażki, Warszawa, Wydawnictwo Naukowe Scholar.

Wysocka E. (2011) Świadomość diagnostyczna zawodowych kuratorów sq̨dowych $w$ kontekście realizacji zadań zwiq̨zanych z diagnozq osobopoznawczq i środowiskowa w: Tożsamość osobowa dewiantów a ich reintegracja społeczna, A. Kieszkowska (red.), Kraków, Oficyna Wydawnicza „Impuls”, s. 339-350. 
Zagórski J. (2008) Dozór kuratora sq̨dowego przy warunkowym zawieszeniu wykonania kary pozbawienia wolności w: Wykonywanie środków probacji i readaptacji skazanych $w$ Polsce, J. Zagórski (red.), Warszawa, Biuro Rzecznika Praw Obywatelskich, s. 69-108.

Zagórski J. (2008) Organizacja pracy i zadania sq̨dowych kuratorów dla dorosłych w: Wykonywanie środków probacji i readaptacji skazanych w Polsce, J. Zagórski (red.), Warszawa, Biuro Rzecznika Praw Obywatelskich, s. 9-30.

Zinkiewicz B. (2015) Profilaktyczny wymiar działalności rodzinnych kuratorów sq̨dowych, Kraków, Oficyna Wydawnicza AFM. 